\title{
CURARE-LIKE ACTION OF POLYMETHYLENE BIS-QUATERNARY AMMONIUM SALTS
}

\author{
BY \\ R. B. BARLOW AND H. R. ING \\ From the Department of Pharmacology, Oxford
}

(Received May 11, 1948)

Tubocurarine chloride was shown by King $(1935,1936)$ to be a bis-tetrahydroisoquinolinium salt containing two quaternary nitrogen atoms. The curare-like blocking of-neuromuscular transmission is a property of "onium cations" in general, and it was thought that the exceptional potency of tubocurarine compared with simple quaternary ammonium ions might be due in part to the presence of two such cationic groups at some optimal distance apart in the same molecule. With this in mind we have prepared and tested for curare-like activity a number of simple bisquaternary ammonium salts in which the nitrogen atoms were directly attached to the terminal carbon atoms of polymethylene chains of different lengths. Such salts may be conveniently referred to as " bis-onium salts"; they were all polymethylene bis-onium dibromides of the general type:<smiles>BrC12CN(CCN3CC3(Br)C1)C2</smiles>

Few compounds of this type have been examined previously; Brieger (1886) observed that tetramethylene bis-trimethylammonium hydroxide had some curare-like action in intact animals, and Ackermann (1921) made similar observations with the analogous ethylene and pentamethylene bistrimethylammonium aurichlorides.

The following salts have been investigated.

1. Bis-trimethylammonium dibromides, $\mathrm{Br}\left\{\mathrm{Me}_{3} \mathrm{~N}\left(\mathrm{CH}_{2}\right)_{n} \mathrm{NMe}_{3}\right\} \mathrm{Br}$, where $n$ was 2, 3, 4, 5 , $7,8,9,10,11,12$, and 13 . They are referred to as BTM followed by the number $(n)$ of methylene groups in the chain; thus trimethylene bis-trimethylammonium dibromide is referred to as BTM3.

2. Bis-triethylammonium dibromides, $\mathrm{Br}\left\{\mathrm{Et}_{3} \mathrm{~N}\left(\mathrm{CH}_{2}\right)_{n} \mathrm{NEt}_{3}\right\} \mathrm{Br}$, where $n$ was 2, 3, 4, 5, $7,8,9,10$, and 13. They are referred to as BTEn.
3. Bis-strychninium dibromides, $\mathrm{Br}\left\{\mathrm{C}_{21} \mathrm{H}_{22} \mathrm{O}_{2} \mathrm{~N}_{2}\left(\mathrm{CH}_{2}\right)_{n} \mathrm{C}_{21} \mathrm{H}_{22} \mathrm{O}_{2} \mathrm{~N}_{2}\right\} \mathrm{Br}$, where $n$ was 2,3 , and 5 . They are referred to as $\mathrm{BS} n$.

4. Bis-quinolinium dibromides, $\operatorname{Br}\left\{\mathrm{C}_{9} \mathrm{H}_{7} \mathrm{~N}\left(\mathrm{CH}_{2}\right)_{n} \mathrm{C}_{9} \mathrm{H}_{7} \mathrm{~N}\right\} \mathrm{Br}$, where $n$ was 3,5 , and 10. They are referred to as $\mathrm{BQ} n$.

5. Bis-(phenyldimethylammonium) dibromides, $\mathrm{Br}\left\{\mathrm{PhMe}_{2} \mathrm{~N}\left(\mathrm{CH}_{2}\right)_{n} \mathrm{NMe}_{2} \mathrm{Ph}\right\} \mathrm{Br}$, where $n$ was 3 and 5. They are referred to as BPDMn.

The following abbreviations will also be used: TM for tetramethylammonium iodide and TE for tetra-ethylammonium iodide.

A brief note on some of the results with these bis-onium salts has already appeared (Barlow and Ing, 1948).

\section{METHOD}

The choice of a method for comparing the curarelike activity of numerous compounds is a matter of some difficulty; older methods have been reviewed by Ing (1936). Recently two methods have been devised for assaying tubocurarine solutions: Holaday (quoted by Bennett, 1941) developed the rabbit headdrop method and Chou (1947) used the isolated phrenic nerve-diaphragm preparation of the rat. We have tried to adapt Chou's method to the comparison of the curare-like activities of our bis-onium salts. Initially the apparatus and procedure were exactly the same as those used by Chou, except that the bath was smaller $(50 \mathrm{ml}$. instead of $100 \mathrm{ml}$.). The condenser discharge stimuli used by Chou were of about $10 \sigma$ duration and as there was a tendency for the nerve to discharge more than once they were later replaced by square wave stimuli of about $0.1 \sigma$ duration. It was also observed during the course of the work that the diaphragm preparation is very sensitive to small changes of temperature and careful control of the bath temperature is necessary.

Chou allowed his tubocurarine chloride solutions to act for three minutes; we retained this feature of the method because if the drug is allowed to produce its full effect so much time is occupied by the poisoning 
process and the eventual wash-out that few comparisons can be effected on one preparation. The disadvantage of this fixed-time method is that drugs may diffuse into the preparation at different rates. Ing and Wright (1931) were faced with the same difficulty in comparing the curare-like activities of tetra-alkylammonium salts on isolated nerve-muscle preparations of the frog, since they chose the time required for complete paralysis to indirect stimulation as their measure of curare-like activity; they were, however, able to show that diffusion rates were negligibie with the nerve sartorius preparation, whereas they were far from negligible with the sciatic-gastrocnemius. The rat diaphragm is, like the frog sartorius, a thin muscle, and we thought that diffusion rates would probably be negligible ; moreover, the latent period between addition of drug to the bath and diminution of the contractions was only a matter of seconds, whereas Ing and Wright found that the frog sartorius preparation exhibited latent periods of several minutes with onium salt solutions more dilute than $1 \mathrm{mM}$.

Our original intention was to use $d$-tubocurarine chloride as a standard and to compare all other bis-onium salts with it, but it was clear that we could only use an assay method of comparison if the doseeffect curves of bis-onium salts and $d$-tubocurarine chloride were parallel. The results of Bülbring and Chou (1947) indicated that the graph of percentage inhibition of the contractions against the logarithm of the dose was probably sigmoid, but when the probit of the percentage inhibition was plotted against the logarithm of the dose we found that the graph was approximately a straight line over the range of $10-50$ per cent inhibition. We compared these regression lines for BTM10 and for $d$-tubocurarine chloride and found that the slopes and positions of the two varied widely and independently from preparation to preparation.

We thought it might be possib'e to obtain consistent results by comparing the doses of the two drugs required to produce a standard percentage inhibition. The ratios of the dose of $d$-tubocurarine chloride in $\mu \mathrm{g}$. to the dose of BTM10 in $\mathrm{ml}$. of $0.1 \mathrm{mM}$ solution required to produce 16 per cent inhibition (probit $=4$ ) on six separate occasions were: $5.1,18.2,4.8,6.2$, 18.5 , and 7.6 ; the first four ratios were obtained with $95 \% \mathrm{O}_{2}+5 \% \mathrm{CO}_{2}$ as the aerating gas, the last two with pure $\mathrm{O}_{2}$. Clearly it was not possible to use $d$-tubocurarine chloride as a standard for comparison. The aerating gas was varied because Chou observed that the activity of tubocurarine chloride was less with pure oxygen than with an oxygen-carbon dioxide mixture $\left(95 \% \mathrm{O}_{2}+5 \% \mathrm{CO}_{2}\right)$; we were unable to detect any such variation with our bis-onium salts.

In the method finally adopted one member (and usually the most active) of a homologous series was chosen as standard and as many as possible of the other members were compared with it on the same preparation, the aim being to find doses of all members which produced approximately the same percentage inhibition of the contractions in three minutes; in this way ratios of approximately equiactive doses were found, in terms of one member of the series, which revealed the way in which activities varied within the series. These ratios, the constancy of which on different preparations may be judged from Table I, were molar ratios, since all concentrations were expressed in mols or miliimols per litre; no attempt was eventually made to relate them to some external standard, such as tubocurarine. The most active members of the BTM series were, however, compared with tubocurarine by means of the rabbit head-drop method with the generous help of Dr. N. K. Dutta.

\section{RESULTS}

Bis-trimethylammonium (BTM) series.-The curare-like activities of members of this series varied in a rather unexpected way. BTM2 was about twice as active as TM; it might be considered simply to contain twice the number of effective blocking groups per molecule. The next three rnembers of the series, BTM3, BTM4, and BTM5, were all very feebly active. BTM7 was about $1 / 6-1 / 7$ th as active as TM, BTM8 was about 50 per cent more active than TM, and BTM9 was 5 to 6 times as active as TM. BTM9, BTM10, BTM11, and BTM12 all had about the same order of activity and BTM13 appeared to be somewhat less active. The relative activities of the more active members of the series, as measured on several preparations, are recorded in Table $I$ in terms of BTM9 $=1$.

TABLE I

MOLAR RATIOS OF CURARE-LIKE ACTIVITY ON THE RAT DIAPHRAGM IN TERMS OF BTM9 $=1$

\begin{tabular}{|c|c|c|c|c|c|c|}
\hline \multirow{2}{*}{ Salt } & \multicolumn{3}{|c|}{ Aeration with pure $\mathrm{O}_{2}$} & \multicolumn{3}{|c|}{ Aeration with $\mathrm{O}_{2}+\mathrm{CO}_{2}$} \\
\hline & Exp. 1 & Exp. 2 & Exp. 3 & Exp. 4 & Exp. 5 & Exp. 6 \\
\hline 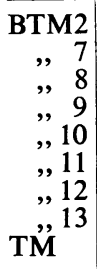 & $\begin{array}{l}0.30 \\
0.02 \\
0.25 \\
1.0 \\
0.6 \\
1.0 \\
0.6 \\
\overline{0.15}\end{array}$ & $\begin{array}{l}0.25 \\
0.02 \\
0.20 \\
1.0 \\
0.8 \\
1.0 \\
0.8 \\
\overline{0.13}\end{array}$ & $\begin{array}{l}- \\
- \\
1.0 \\
0.6 \\
1.0 \\
0.6 \\
0.4 \\
-\end{array}$ & $\begin{array}{l}0.30 \\
0.25 \\
1.0 \\
0.6 \\
1.0 \\
0.6 \\
0.5 \\
0.13\end{array}$ & $\begin{array}{l}0.5 \\
0.3 \\
1.0 \\
1.3 \\
1.3 \\
- \\
\overline{0.2}\end{array}$ & $\begin{array}{l}\overline{-} \\
\overline{1.0} \\
\overline{1.3} \\
\overline{-} \\
\overline{0.2}\end{array}$ \\
\hline
\end{tabular}

Superficially these results suggest that members of the BTM series behave rather like the analogous alkyltrimethylammonium salts in which the alkyl group contains (to the nearest whole number) half the number of carbon atoms in the polymethylene chain; thus in the series $\mathrm{Me}_{3} \mathrm{~N} \cdot \mathrm{C}_{n} \mathrm{H}_{2 n+1}$, the least active on frog muscle are those in which $n=2$ or 3 and cations in which $n=4$ to 8 are all about as 
active as TM (Ing and Wright, 1931). In the BTM series the least active contain polymethylene chains of 3, 4, and 5 carbon atoms (the hexamethylene member was not prepared) ; members with polymethylene chains of 7 to 13 carbon atoms are all much more active. However, it is doubtful whether it is legitimate to compare activities on a rat preparation with those on frog preparations.

In the rabbit head-drop test the members of this series displayed entirely different orders of activity ; as will be seen in Table II activity rose to a pronounced maximum for BTM10, which was some three times as potent, weight for weight, as $d$-tubocurarine chloride and about 10 times as active as the salts with $8,11,12$, and 13 carbon atoms in the polymethylene chain. Only BTM9 approached BTM10 in activity, being about a third as active.

TABLE II

COMPARISON OF BTM SERIES WITH TUBOCURARINE CHLORIDE IN RABBIT HEAD-DROP TEST

\begin{tabular}{|c|c|c|c|c|}
\hline \multicolumn{2}{|c|}{ Salt } & $\begin{array}{c}\text { Mean } \\
\text { head-drop } \\
\text { dose } \pm \text { S.E. } \\
\mu \mathrm{g} . / \mathrm{kg} . \\
\end{array}$ & $\begin{array}{l}\text { No. of } \\
\text { rabbits }\end{array}$ & $\begin{array}{l}\text { Relative } \\
\text { potency }\end{array}$ \\
\hline 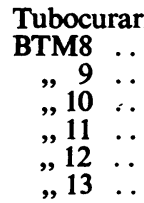 & $\begin{array}{cc}\text { chloride } \\
\ldots & . \\
\ldots & . \\
\ldots & . \\
\ldots & \ldots \\
\ldots & \ldots\end{array}$ & $\begin{array}{c}261 \pm 14 \\
808 \pm 52 \\
290 \pm 27 \\
78 \pm 20 \\
657 \pm 107 \\
783 \pm 81 \\
857 \pm 43\end{array}$ & $\begin{array}{l}5 \\
2 \\
4 \\
6 \\
2 \\
2 \\
2\end{array}$ & $\begin{array}{l}1 \\
0.3 \\
0.9 \\
3.3 \\
0.4 \\
0.3 \\
0.3\end{array}$ \\
\hline
\end{tabular}

Bis-triethylammonium (BTE) series.-The behaviour of members of this series had some resemblance to that of alkyltriethylammonium salts on frog muscle. Kulz (1922) recorded a steady increase of activity in the series Et $\mathrm{N}_{2} \mathrm{C}_{n} \mathrm{H}_{2 n+1}$ from $n=2$ to $n=8$, and we have observed (on the rat diaphragm) a steady rise in activity from BTE4 to BTE13. The latter was about a hundred times as active as BTE4 and somewhat more active than BTM9. In the rabbit head-drop test BTE13, though the most active of the series on the rat diaphragm, was less active than BTM9 and about two-fifths as active as tubocurarine. BTE2 and BTE3 were only feebly active ; BTE2 resembled TE in augmenting the response of the muscle to stimuli which had previously given maximal contractions (see below).

Bis-strychninium (BS) series.-The rat diaphragm is less sensitive to methylstrychninium salts than the frog's sartorius; thus, whereas Cowan and Ing (1934) found that methylstrychninium iodide was as active as tubo- curarine chloride* on the isolated frog's sartorius ( $R$. esculenta), we found that the chloride was not more active than TM on the rat diaphragm. The rat diaphragm is more sensitive to $T M$ than the frog's sartorius: thus, $0.25 \mathrm{mM}$ solutions of TM produced 50 per cent inhibition in 3 min., whereas Ing and Wright (1931, Fig. 1) found that $2.0 \mathrm{mM}$ solutions were required to produce a similar inhibition of the isolated frog's sartorius in a similar time. At the same time TM is much less potent than tubocurarine on the rat diaphragm.

BS2 was more than twice as active as methylstrychninium chloride on the rat diaphragm (compare BTM2 and TM), but BS3 and BS5 were not significantly less active than BS2, a result which contrasts strongly with the feeble activities of the corresponding members of the BTM series. All bis-strychninium salts produced augmentation of the contractions of the rat diaphragm before inhibition.

Bis-quinolinium $(B Q)$ series.-BQ3 and $\mathrm{BQ} 5$, unlike the corresponding members of the BTM series, show moderate activity. BQ10 was much less active than was expected; it was only about as active as BQ5, but it had a powerful augmenting effect on the muscle contractions, which must compete with the inhibitory effect.

Bis (phenyldimethylammonium) (BPDM) series. -Only two, BPDM3 and BPDM5, were prepared and tested, and, like the corresponding $B Q$ compounds, they were both moderately active.

Augmentation effect.-It has already been noted that some bis-onium salts increased the size of the contractions of the rat diaphragm to maximal stimuli. With some salts, e.g., BTE2, this was the main effect and inhibition only occurred after a lapse of time much longer than $3 \mathrm{~min}$.; with most salts the augmentation was only observed in some preparations. In the BTE series, apart from BTE2, which invariably showed it, the augmentor effect was observed from time to time with all the other members except BTE13 ; it was less frequently observed in the BTM series. Some preparations appeared to be much more sensitive to this augmentation (or possibly much less sensitive to the inhibitory effect) than others, and this variability in the response of preparations to these two opposing effects was probably the main reason for the difficulty in obtaining consistent estimates of relative activities; moreover, there was rarely a clear differentiation between concentrations which produced mainly augmentation and those

* Thé specimens used were King's crystalline $d$-tubocurarine chloride, at that time recently isolated, and Boehm's original amorphous alkaloid from tubocurare; they were wrongly referred to as "curarine chlorides." 
which produced mainly inhibition. Three salts, BTE2, BS2, and BQ10, did, however, show such differentiation; they caused augmentation at concentrations much lower than those required to produce inhibition. With BS2 it was possible to obtain, within the 3-min. interval, augmentation with low doses and inhibition with larger doses, intermediate doses could also be found with which the two effects cancelled each other at the end of $3 \mathrm{~min}$.

The cause of the augmentation is unknown; its prominence with BTE2 recalls the similar effect of TE, which has been known for many years and appears to be due to a direct action upon the motor nerve (Cowan and Ing, 1933, 1935; Cowan and Walter, 1937). At the same time the augmentation resembles superficially the effect of anticholinesterase drugs and consequently representative bisonium salts were tested as inhibitors of the cholinesterase of caudate nucleus (dog) with acetylcholine as substrate.

The following bis-onium salts were tested in this way: BTM9, BTE8, and BTE13 at concentrations which will inhibit the contractions of the rat diaphragm; BTE2, BS2, and BQ10 at concentrations which will cause augmentation only. As will be seen in Table III, BTM9 had only slight inhibitory effect on the enzyme but all the other salts inhibited it markedly at these concentrations. TM $\left(2 \times 10^{-4} M\right)$ had no inhibitory effect although augmentation was sometimes observed with this salt. BQ10 $\left(3 \times 10^{-5} \mathrm{M}\right)$ was also a powerful inhibitor of the cholinesterase of horse serum. This enzyme was also inhibited by BTE8 $\left(3 \times 10^{-4} M\right)$ and by BTE13 $\left(3 \times 10^{-5} M\right)$ but not by TM or TE $\left(3 \times 10^{-4} M\right)$.

TABLE III

INHIBITION OF CHOLINESTERASE (CAUDATE NUCLEUS) WITH ACETYLCHOLINE $\left(6 \times 10^{-4} M\right)$ AS SUBSTRATE

\begin{tabular}{|c|c|c|c|c|}
\hline \multicolumn{3}{|c|}{ Salt } & $\begin{array}{l}\text { Molar } \\
\text { conc. }\end{array}$ & $\begin{array}{c}\text { Percentage } \\
\text { inhibition }\end{array}$ \\
\hline $\begin{array}{l}\text { BTM9 } \\
\text { BTE8 } \\
\text { BTE13 }\end{array}$ & $\begin{array}{l}\cdots \\
\cdots \\
\cdots\end{array}$ & $\begin{array}{l}\cdots \\
\cdots \\
\cdots\end{array}$ & $\begin{array}{l}3.7 \times 10^{-5} \\
3.3 \times 10^{-4} \\
3.7 \times 10^{-5}\end{array}$ & $\begin{array}{r}5.4 \\
78.0 \\
78.4\end{array}$ \\
\hline $\begin{array}{l}\text { BTE2 } \\
\text { BS2 } \\
\text { BQ10 }\end{array}$ & $\begin{array}{l}\cdots \\
\cdots \\
\ldots\end{array}$ & $\begin{array}{l}\ldots \\
\ldots \\
\ldots\end{array}$ & $\begin{array}{l}3.7 \times 10^{-3} \\
1.9 \times 10^{-4} \\
3.3 \times 10^{-5}\end{array}$ & $\begin{array}{l}46.0 \\
30.5 \\
93.0\end{array}$ \\
\hline
\end{tabular}

\section{Discussion}

The main purpose of this work, which was begun in 1946, was to discover whether suitable separation of two quaternary ammonium groups in the same molecule would lead to enhancement of curare-like activity. The polymethylene bistrimethylammonium series is the simplest possible type of bis-onium salt and it is of considerable interest that with a decamethylene chain a salt (BTM10) is obtained which is not only five to six times as active as TM on the rat diaphragm but also three times as potent as tubocurarine chloride in the rabbit head-drop test. Paton and Zaimis (1948) have independently confirmed the latter figure for the di-iodide corresponding to BTM 10 .

The occurrence of such high activity with a 10-carbon chain separating the two nitrogen atoms is particularly interesting. It may not be entirely fanciful to point out that in the tubocurarine structure I (King, 1948) the shortest route between the two nitrogen atoms traverses ten atoms (9 carbon, of which only one is extra-annular, and 1 oxygen); there are two such routes. The tubocurarine structure is not completely rigid, but the distance
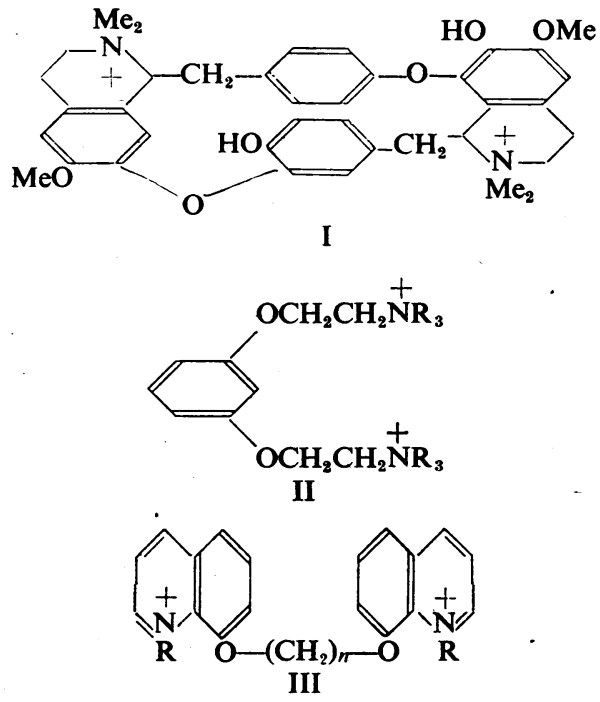

between the nitrogen atoms will vary little. Polymethylene bis-onium ions will be flexible structures capable of assuming a large number of configurations, subject only to the mutual repulsion of the two similarly charged nitrogen atoms. The decamethylene chain should allow distances between the two nitrogen atoms similar to those which occur in tubocurarine, and the same will probably be true for slightly shorter and for longer chains. If it be assumed that the exceptional potency of tubocurarine is due in part to the presence of two quaternary nitrogen atoms at some 
optimal distance apart, we should expect high curare-like activity to occur with bis-onium ions capable of a similar separation of the two nitrogen atoms ; such separation would probably involve a chain of at least 8 atoms. It is noteworthy that of the highly active bis-onium salts of types II and III studied by Bovet et al. $(1946,1947)$ the most active have 8 to 12 atoms between the two nitrogen atoms.

A reason may also be tentatively suggested for the occurrence of high activity in compounds containing two quaternary nitrogen atoms: if, in virtue of the distance between them, both charged centres are held by the " receptive substance," simultaneous dissociation of both centres from the receptors will be highly improbable and, so long as one centre is held, the re-attachment of the second is made more probable owing to the proximity of the ion to the receptive substance.

Our results with the BTM series indicate that the sensitivity of the rat diaphragm to bis-onium salts differs greatly from that of the rabbit. We also observed that the rat diaphragm was less sensitive to methylstrychninium and more sensitive to TM than the frog's sartorius ( $R$. esculenta). Paton and Zaimis (1948) have noted that, compared with tubocurarine, BTM8 is some nine times as active in the cat as in the rabbit, and Brown and Dias (1948) have reported a striking difference in the sensitivities of Leptodactylus ocellatus and Rana temporaria to tubocurarine chloride. These differences in species sensitivity suggest that synthetic curare-like drugs ought to be tested on a variety of species.

The inhibition of cholinesterases by some of our bis-onium salts was unexpected and the specificity of this effect would probably repay further investigation. There is a rough correlation between the intensity of this effect and that of the augmentor effect in the rat diaphragm, but other possible explanations of the latter effect have not been explored.

\section{Chemical Section}

The bis-onium dibromides were prepared by heating polymethylene dibromides in ethanol with a large excess of the requisite tertiary base for from 5 to 24 hours. In the BTM series 33 per cent $(w / v)$ aqueous trimethylamine was used; a pressure bottle was unnecessary.

Ethylene bis-onium dibromides were less easily prepared; BQ2 and BPDM2 could not be isolated. The product of heating ethylene dibromide with strychnine in ethanol is bromoethyl-strychninium bromide (Found: $\mathrm{N}, 5.62$. $\mathrm{C}_{23} \mathrm{H}_{26} \mathrm{O}_{2} \mathrm{~N}_{2} \mathrm{Br}_{2}$ requires $\mathrm{N}, 5.38 \%$ ). BS2 was prepared by heating this half-way product with excess strychnine at $180^{\circ} \mathrm{C}$. for 7 hours in glycerol as solvent; the glycerol was removed, after acetylation, as triacetin by ether extraction; excess strychnine was extracted with chloroform; yield almost theoretical.

Condensations of polymethylene dibromides with quinoline and dimethylaniline give red and blue byproducts respectively. The formation of red products with quinoline may be partly, and of blue products with dimethylaniline completely, suppressed by carrying out the reaction in an inert atmosphere $\left(\mathrm{N}_{2}\right.$ or $\mathrm{CO}_{2}$ ); coloured products are best purified by pouring the reaction solution through a charcoal column.

Bis-onium dibromides are white crystalline solids. They are often both hydrated and hygroscopic; their analysis has presented some difficulty. Some salts could not be dried to a constant water content and the anhydrous salts were too hygroscopic for successful analysis ; it was necessary to analyse the hydrated salt and use the experimentally determined water content in calculating the theoretical carbon and hydrogen figures. When an attempt was made to analyse some anhydrous salts, in particular BTE11 and BTE13, the specimens absorbed appreciable amounts of water between weighing and combustion; this can be detected by the high value for hydrogen and the low value for carbon, and if the excess hydrogen is assumed to be derived from water a "corrected" value for carbon can be obtained.

Analyses are by Drs. Weiler and Strauss. All m.p.s are uncorrected.

Ethylene bis-trimethylammonium dibromide. BTM2.

Crystallized from ethanol. No m.p. below 280 .

Found: $\mathrm{C}, 31.5 ; \mathrm{H}, 7.9 . \mathrm{C}_{8} \mathrm{H}_{22} \mathrm{~N}_{2} \mathrm{Br}_{2}$ required C, $31.4 ; \mathrm{H}, 7.2 \%$.

Trimethylene bis-trimethylammonium dibromide. BTM3.

Crystallized from ethanol. Loses water above $105^{\circ}$ but does not melt below $250^{\circ}$. Roth (1881) does not record a m.p.

Found: $\mathrm{C}, 32.5 ; \mathrm{H}, \quad$ 7.87. Calculated for $\mathrm{C}_{9} \mathrm{H}_{24} \mathrm{~N}_{2} \mathrm{Br}_{2}, 1 \mathrm{H}_{2} \mathrm{O}: \mathrm{C}, 32.0 ; \mathrm{H}, 7.70 \%$.

Tetramethylene bis-trimethylammonium dibromide. BTM4. Crystallized from ethanol. Loses water below $110^{\circ}$ but does not melt below $305^{\circ}$. v. Braun and Lemke (1922) recorded m.p. $295^{\circ}$ (dec.).

Found: $\mathrm{C}, 32.7 ; \mathrm{H}, 7.80$. Calculated for $\mathrm{C}_{10} \mathrm{H}_{26} \mathrm{~N}_{2} \mathrm{Br}_{2}, 2 \mathrm{H}_{2} \mathrm{O}$ : C, 32.4; H. $8.11 \%$.

Pentamethylene bis-trimethylammonium dibromide. BTM5. Crystallized from ethanol. No m.p. below $280^{\circ}$.

Found: $\mathrm{C}, 37.2 ; \mathrm{H}, 7.83 ; \mathrm{C}_{11} \mathrm{H}_{28} \mathrm{~N}_{2} \mathrm{Br}_{2}$ requires C, $37.6 ; \mathrm{H}, 8.04 \%$.

Heptamethylene bis-trimethylammonium dibromide. BTM7.

Crystallized from ethanol and ether. m.p. $113^{\circ}$.

Found: $\mathrm{C}, 38.3 ; \mathrm{H}, 8.44 ; \mathrm{H}_{2} \mathrm{O}, 7.86 . \mathrm{C}_{13} \mathrm{H}_{32} \mathrm{~N}_{2} \mathrm{Br}_{2}$, $1.8 \mathrm{H}_{2} \mathrm{O}$ requires $\mathrm{C}, 38.3 ; \mathrm{H}, 8.70 ; \mathrm{H}_{2} \mathrm{O} 7.86 \%$.

Octamethylene bis-trimethylammonium dibromide. BTM8.

Crystallized from ethanol. Loses water above $120^{\circ}$ but does not melt below $280^{\circ}$. 
Found : C, $40.0 ; \mathrm{H}, 8.94 ; \dot{\mathrm{H}}_{2} \mathrm{O}, 7.38 . \mathrm{C}_{14} \mathrm{H}_{34} \mathrm{~N}_{2} \mathrm{Br}_{2}$, $1.7 \mathrm{H}_{2} \mathrm{O}$ requires $\mathrm{C}, 39.9 ; \mathrm{H}, 8.88 ; \mathrm{H}_{2} \mathrm{O}, 7.38 \%$.

Nonamethylene bis-trimethylammonium dibromide. BTM9.

Crystallized from ethanol, acetone and ether. m.p. $101^{\circ}$.

Found : C, $41.3 ; \mathrm{H}, 8.72 ; \mathrm{H}_{2} \mathrm{O}, 7.15 . \mathrm{C}_{15} \mathrm{H}_{36} \mathrm{~N}_{2} \mathrm{Br}_{2}$, $1.7 \mathrm{H}_{2} \mathrm{O}$ requires $\mathrm{C}, 41.3 ; \mathrm{H}, 9.05 ; \mathrm{H}_{2} \mathrm{O}, 7.15 \%$.

Decamethylene bis-trimethylammonium dibromide. BTM10.

Crystallized from ethanol. m.p. $113^{\circ}$.

Found: $\mathrm{H}_{2} \mathrm{O}, 7.12$. $\quad \mathrm{C}_{16} \mathrm{H}_{38} \mathrm{~N}_{2} \mathrm{Br}_{2}, 2 \mathrm{H}_{2} \mathrm{O}$ requires $\mathrm{H}_{2} \mathrm{O}$, 7.35. Sample dried at $100^{\circ}$ in high vacuum. Found : $\mathrm{C}, 46.3 ; \mathrm{H}, 9.28 . \quad \mathrm{C}_{16} \mathrm{H}_{38} \mathrm{~N}_{2} \mathrm{Br}_{2}$ requires C, $45.9 ; \mathrm{H}, 9.10 \%$.

Undecamethylene bis-trimethylammonium dibromide. BTM11.

Crystallized from ethanol. m.p. $104^{\circ}$.

Found : $\mathrm{H}_{2} \mathrm{O}, 17.4$. $\quad \mathrm{C}_{17} \mathrm{H}_{40} \mathrm{~N}_{2} \mathrm{Br}_{2}, 5 \mathrm{H}_{2} \mathrm{O}$ requires $\mathrm{H}_{2} \mathrm{O}$, 17.3. Sample dried at $100^{\circ}$ in high vacuum. Found : $\mathrm{C}, 46.6 ; \mathrm{H}, 9.44 . \mathrm{C}_{17} \mathrm{H}_{40} \mathrm{~N}_{2} \mathrm{Br}_{2}$ requires C, 47.2 ; H, 9.26. "Corrected" value : C, $47.2 \%$.

Dodecamethylene bis-trimethylammonium dibromide. BTM12.

$250^{\circ}$.

Crystallized from ethanol and ether. No m.p. below

Found : C, $48.0 ; \mathrm{H}, 9.17 ; \mathrm{H}_{2} \mathrm{O}$, nil. $\mathrm{C}_{18} \mathrm{H}_{42} \mathrm{~N}_{2} \mathrm{Br}_{2}$ requires $\mathrm{C}, 48.4$; $\mathrm{H}, 9.42 \%$.

Tridecamethylene bis-trimethylammonium dibromide. BTM13.

- Crystallized from ethanol, acetone, and ether. No definite m.p.

Found : $\mathrm{H}_{2} \mathrm{O}$, 8.65. $\mathrm{C}_{10} \mathrm{H}_{44} \mathrm{~N}_{2} \mathrm{Br}_{2}, 2.5 \mathrm{H}_{2} \mathrm{O}$ requires $\mathrm{H}_{2} \mathrm{O}$, 9.23. Sample dried at $100^{\circ}$ in high vacuum. Found : $\mathrm{C}, 50.0 ; \mathrm{H}, 9.63 . \mathrm{C}_{19} \mathrm{H}_{44} \mathrm{~N}_{2} \mathrm{Br}_{2}$ requires C, 49.6 ; H, $9.57 \%$.

Ethylene bis-triethylammonium dibromide. BTE2.

Crystallized from ethanol. m.p. 246 ${ }^{\circ}$. Lucius (1907) recorded m.p. $245-246^{\circ}$.

Trimethylene bis-triethylammonium dibromide. BTE3.

Crystallized from ethanol. m.p. $264^{\circ}$ (decomp.).

Lucius (1907) recorded m.p. $245^{\circ}$.

Found: $\mathrm{N}$, 7.06. Calculated for $\mathrm{C}_{15} \mathrm{H}_{36} \mathrm{~N}_{2} \mathrm{Br}_{2}$ : N, $6.93 \%$.

Tetramethylene bis-triethylammonium dibromide. BTE4. Crystallized from ethanol and ether. m.p. $273^{\circ}$ (decomp.).

Found : $\mathrm{C}, 45.7 ; \mathrm{H}, 8.83 . \mathrm{C}_{16} \mathrm{H}_{38} \mathrm{~N}_{2} \mathrm{Br}_{2}$ requires C, 45.9 ; H, $9.09 \%$.

Pentamethylene bis-triethylammonium dibromide. BTE5. Crystallized from ethanol. No m.p. below $250^{\circ}$.

Found : $\mathrm{N}, 6.05$. $\mathrm{C}_{17} \mathrm{H}_{40} \mathrm{~N}_{2} \mathrm{Br}_{2}$ requires $\mathrm{N}, 6.48 \%$.

Heptamethylene bis-triethylammonium dibromide. BTE7. Crystallized from ethanol, and ether. m.p. $274^{\circ}$ (decomp.).

Found : $\mathrm{C}, 49.3 ; \mathrm{H}, 9.35 . \mathrm{C}_{19} \mathrm{H}_{44} \mathrm{~N}_{2} \mathrm{Br}_{2}$ requires C, $49.6 ; \mathrm{H}, 9.57 \%$.
Octamethylene bis-triethylammonium dibromide. BTE8. Crystallized from ethanol, methylethyl ketone, ethyl acetate and ether. m.p. $240^{\circ}$ (decomp.).

Found: $\mathrm{H}_{2} \mathrm{O}$, 16.17. $\mathrm{C}_{20} \mathrm{H}_{46} \mathrm{~N}_{2} \mathrm{Br}_{2}, 5 \mathrm{H}_{2} \mathrm{O}$ requires $\mathrm{H}_{2} \mathrm{O}$, 15.95. Sample dried at $100^{\circ}$ in high vacuum. Found: $\mathrm{C}, 50.1 ; \mathrm{H}, 9.58 . \quad \mathrm{C}_{20} \mathrm{H}_{46} \mathrm{~N}_{2} \mathrm{Br}_{2}$ requires $\mathrm{C}, 50.6$; $\mathrm{H}, 9.71 \%$.

Nonamethylene bis-triethylammonium dibromide. BTE9. Crystallized from ethanol, acetone and ether. m.p. $211^{\circ}$.

Found : $\mathrm{C}, 51.8 ; \mathrm{H}, 9.62 . \mathrm{C}_{21} \mathrm{H}_{48} \mathrm{~N}_{2} \mathrm{Br}_{2}$ requires C, $51.6 ; \mathrm{H}, 9.84 \%$.

Decamethylene bis-triethylammonium dibromide. BTE10. Crystallized from ethanol, acetone and ether. m.p. $235^{\circ}$.

Found : $\mathrm{C}, 52.6 ; \mathrm{H}, 9.91 . \quad \mathrm{C}_{22} \mathrm{H}_{50} \mathrm{~N}_{2} \mathrm{Br}_{2}$ requires C, 52.6 ; H, 9.99\%.

Tridecamethylene bis-triethylammonium dibromide. BTE13. Crystallized from ethanol, acetone and ether. m.p. 75-76 ${ }^{\circ}$.

Found : $\mathrm{H}_{2} \mathrm{O}, 15.48$. $\quad \mathrm{C}_{25} \mathrm{H}_{56} \mathrm{~N}_{2} \mathrm{Br}_{2}, 5.5 \mathrm{H}_{2} \mathrm{O}$ requires $\mathrm{H}_{2} \mathrm{O}, 15.5$. Sample dried at $100^{\circ}$ in high vacuum. Found: C, 54.1; $\mathrm{H}$, 10.55. $\mathrm{C}_{25} \mathrm{H}_{56} \mathrm{~N}_{2} \mathrm{Br}_{2}$ requires $\mathrm{C}$, 55.1; $\mathrm{H}, 10.3$. "Corrected" value : C, $55.0 \%$.

Ethylene bis-strychninium dibromide. BS2.

Crystallized from ethanol. No m.p. below $300^{\circ}$.

Found : $\mathrm{N}, 6.76 . \mathrm{C}_{44} \mathrm{H}_{48} \mathrm{O}_{2} \mathrm{~N}_{4} \mathrm{Br}_{2}$ requires $\mathrm{N}, 6.55 \%$.

Trimethylene bis-strychninium dibromide. BS3.

Crystallized from water ; saturated solutions contain about $3.2 \mathrm{~g}$. $/ 1$.

Found : $\mathrm{N}, 6.88$. $\mathrm{C}_{45} \mathrm{H}_{50} \mathrm{O}_{2} \mathrm{~N}_{4} \mathrm{Br}_{2}$ requires $\mathrm{N}, 6.45 \%$.

Pentamethylene bis-strychninium dibromide. BS5.

Crystallized from water ; saturated solutions contain about $1.6 \mathrm{~g} . / 1$. No m.p. below $250^{\circ}$.

Found : $\mathrm{N}, 6.20$. $\mathrm{C}_{47} \mathrm{H}_{54} \mathrm{O}_{2} \mathrm{~N}_{4} \mathrm{Br}_{2}$ requires $\mathrm{N}, 6.24 \%$.

Trimethylene bis-quinolinium dibromide. BQ3.

Crystallized from ethanol. m.p. $247^{\circ}$.

Found: $\mathrm{N}, 6.35$. $\mathrm{C}_{21} \mathrm{H}_{20} \mathrm{~N}_{2} \mathrm{Nr}_{2}$ requires $\mathrm{N}, 6.10 \%$.

Pentamethylene bis-quinolinium dibromide. BQ5. Crystallized from ethanol. m.p. $195^{\circ}$.

Found : C, 53.6; $\mathrm{H}$, 5.52. $\quad \mathrm{C}_{23} \mathrm{H}_{24} \mathrm{~N}_{2} \mathrm{Br}_{2}, 2 \mathrm{H}_{2} \mathrm{O}$ requires $\mathrm{C}, 53.1 ; \mathrm{H}, 5.37 \%$.

Decamethylene bis-quinolinium dibromide. BQ10. Crystallized from ethanol and ether. m.p. $113^{\circ}$.

Found : $\quad \mathrm{H}_{2} \mathrm{O}$, 5.88. $\quad \mathrm{C}_{28} \mathrm{H}_{34} \mathrm{~N}_{2} \mathrm{Br}_{2}, 2 \mathrm{H}_{2} \mathrm{O}$ requires $\mathrm{H}_{2} \mathrm{O}$, 6.06. Sample dried at $100^{\circ}$ in high vacuum. Found : $\mathrm{C}, 60.3 ; \mathrm{H}, 6.56 . \mathrm{C}_{28} \mathrm{H}_{34} \mathrm{~N}_{2} \mathrm{Br}_{2}$ requires C, $60.2 ; \mathrm{H}, 6.09$.

Trimethylene bis-phenyldimethylammonium dibromide. BPDM3.

Crystallized from ethanol and ether. m.p. $213^{\circ}$ (dec.).

Found : $\mathrm{N}, 6.30 . \mathrm{C}_{19} \mathrm{H}_{28} \mathrm{~N}_{2} \mathrm{Br}_{2}$ requires $\mathrm{N}, 6.30 \%$.

Pentamethylene bis-phenyldimethylammonium dibromide. BPDM5.

Crystallized from ethanol and ether. m.p. $226^{\circ}$.

Found : N, 5.52. $\mathrm{C}_{21} \mathrm{H}_{32} \mathrm{~N}_{2} \mathrm{Br}_{2}$ requires $\mathrm{N}, 5.93 \%$. 


\section{SUMMARY}

(1) The following series of polymethylene bisquaternary ammonium dibromides have been prepared and tested for curare-like activity on the phrenic nerve-diaphragm preparation of the rat ( $n=$ number of carbon atoms in the polymethylene chain) :-bis-trimethylammonium series, $n=2,3,4$, $5,7,8,9,10,11,12$, and 13 ; bis-triethylammonium series, $n=2,3,4,5,7,8,9,10$, and 13 ; bis-strychninium series, $n=2,3$, and 5 ; bis-quinolinium series, $n=3,5$, and 10 ; bis-(phenyldimethylammonium) series, $n=3$ and 5 .

(2) In the bis-trimethyl series, the salt with $n=2$ is about twice as active as tetramethylammonium iodide ; salts with $n=3,4$, or 5 are only feebly active ; activity increases from $n=7$ to $n=9$; salts with $n=9,10,11$, and 12 are all about 5-6 times as active as tetramethylammonium.

(3) In the bis-triethyl series, salts with $n=2$ or 3 are relatively inactive ; activity increases from $n=4$ to $n=13$, the last member being somewhat more active than the bis-trimethyl member in which $n=9$.

(4) None of the members of the other three series was so active as the most active members of the bis-trimethyl series.

(5) In the rabbit head-drop test the bis-trimethyl member with $n=9$ was nearly as active as tubocurarine chloride; the member with $n=10$ was about three times as active. The bis-triethyl member with $n=13$ was about two-fifths as active as tubocurarine chloride.

(6) Some bis-onium salts, particularly bis-triethylammonium, bis-strychninium, and bis-quinolinium, augment the response of the rat diaphragm to maximal stimuli and inhibit the cholinesterase of caudate nucleus (dog).

Our thanks are due to Dr. N. K. Dutta, who carried out the rabbit head-drop tests.

This work was completed during the tenure of a grant from the Medical Research Council held by R. B. B.

\section{REFERENCES}

Ackermann, D. (1921). Munch med. Wschr., 12.

Barlow, R. B., and Ing. H. R. (1948). Nature, Lond., 161, 718.

Bennett, A. E. (1941). Amer. J. Psychiat., 97, 1040.

Bovet, D., Courvoisier, S., Ducrot, R., and Horclois, R. (1946). C.R. Acad. Sci., Paris, 223, 597.

Bovet, D., Depierre, F., and Lestrange, Y. de (1947). C.R. Acad. Sci., Paris, 225, 74.

Braun, J. v., and Lemke, G. (1922). Ber. dtsch. chem. Ges. $55,3530$.

Brieger, L. (1886). Untersuchungen über Ptomaine, Part III, p. 104. Berlin : A. Hirschwald.

Brown, G. L., and Dias, M. V. (1948). Nature, Lond., 161, 234.

Bülbring, E., and Chou, T. C. (1947). Brit. J. Pharmacol., $2,8$.

Chou, T. C. (1947). Brit. J. Pharmacol., 2, 1.

Cowan, S. L., and Ing. H. R. (1933). J. Physiol., 79, 75.

Cowan, S. L., and Ing, H. R. (1934). J. Physiol., 82, 432.

Cowan, S. L., and Ing, H. R. (1935). J. Physiol., 84, 90.

Cowan, S. L., and Walter, W. G. (1937). J. Physiol., 81, 101.

Ing, H. R. (1936). Physiol. Rev., 16, 527.

Ing, H. R., and Wright, W. M. (1931). Proc. Roy. Soc., $109 B, 337$.

King, H. (1935). J. chem. Soc., 1381.

King, H. (1936). J. Jhem. Soc., 1276.

King, H. (1948). J. chem. Soc., 265.

Kulz, F. (1922). Pfluger's Arch., 195, 623.

Lucius, R. (1907). Arch. Pharm., 245, 246.

Paton, W. D. M., and Zaimis, E. J. (1948). Nature, Lond., 161,718 .

Roth, C. F. (1881). Ber. dtsch. chem. Ges., 14, 1351. 